\title{
NOTE ON THE VOLUME CONCENTRATION OF CONDENSED MILK,
}

\author{
By A. McGiLL.
}

THE purchaser of condensed milk, as a rule, thinks of its concentration in terms of volume rather than weight; and values a pint of the article more or less highly as he takes it to represent more or less than, say, three pints of the milk used in its preparation. A. H. Allen (see Analyst, xxi., p. 281) has given a formula for calculating, from the results of analysis, the volume concentration of any sample. His formula involves a knowledge of the specific gravity of the sample, and assumes the normal character of the milk from which the condensed article is made.

I would suggest the solids-not-fat instead of the total solids as a basis for calculation of the concentration. It is mainly in the partial or entire removal of the fat before manufacture that condensed milks differ from each other; and although, in the case of a whole milk, it makes little difference whether total solids or solidsnot-fat is employed in the calculation, the error is very considerable when a skimmed milk is in question.

The following examples, taken from the analyses of Pearmain and Moor (Analyst, xx., 272), illustrate this:

\section{Brand.}

Milkmaid ... Lancer ...

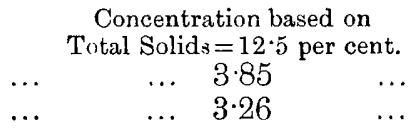

Concentration based on

... $3.85 \quad \ldots$
Concentration based on Solids-not-Fat $=8 \cdot 5$ per cent.

...

... $\quad 4 \cdot 74$

These figures are calculated by Mr. Allen's formula, in which the density of normal milk is taken as 1 , and that of condensed milk as 1.28. My own experience shows that most samples of sweetened condensed milk have a gravity of 1.31 to 1.33 ; and I prefer to use the number 1.03 , instead of unity, as the average density of normal milk. The density of condensed milk is not easily taken upon the sample itself. I prepare a solution of 50 grammes to $250 \mathrm{c.c}$, and from the density of this solution calculate that of the original sample by the formula:

$$
\text { Original density }=\frac{1}{6-5 a} \text {, when }(a)=\text { density of the dilute milk. }
$$

If these changes be made, the numbers already given for Milkmaid and Lancer brands will become $4 \cdot 01$ and $4 \cdot 75$; instead of 4.02 and $4 \cdot 74$; so that, for practical purposes, it is of little consequence which pair of numbers is used. If, however, the true density of the sample be used in calculation, while the density of normal milk is taken as unity, the numbers become $4 \cdot 13$ and $4 \cdot 84$ respectively.

The formulæ used may be written as follows :

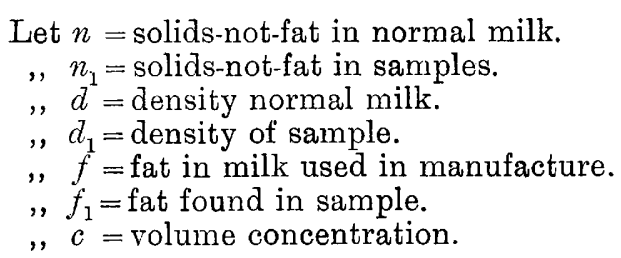




$$
\text { Then, } \begin{aligned}
c & =\frac{n_{1} \times d_{1}}{n \times d}=\frac{n_{1} \times d_{1}}{8.5 \times 1.03}=\frac{n_{1} \times d_{1}}{8.755} . \\
f & =\frac{n \times f_{1}}{n_{1}}=\begin{array}{c}
8.5 f_{1} . \\
n_{1}
\end{array}
\end{aligned}
$$

Thus, the fat percentage in the original milk used in preparing the Milkmaid brand is found to be 3.515 .

Laboratory of the Inland Revende Departaent, Ottawa, January 15, 1898.

\section{THE INSTITUTE OF CHEMISTRY.}

THE annual dinne of the Fellows and Associates of the Institute of Chemistry took place last night at the Trocadero Restaurant, Piccadilly Circus. The president, Dr. T. Stevenson (official analyst to the Home Office), occupied the chair, and the large company present included Lord Reay, Mr. Justice Byrne, Sir J. Evans (treasurer Royal Society), Sir E. Frankland, Sir H. T. Wood (secretary of the Society of Arts), Mr. K. E. Digby, Dr. Bernard Dyer, Dr. W. J. Russell, Dr. Thorpe, Mr. T. H. Elliott, Mr. J. F. Moulton, Q.C., Mr. H. Kearley, M.P., Mr. H. H. Cozens-Hardy, M.P., Professor Dewar, Dr. J. H. Gladstone, Dr. Ludwig Mond, Mr. W. Hills (president of the Pharmaceutical Society), Dr. H. E. Armstrong, Dr. W. J. Sykes, Dr. J. A. Voelcker, Mr. Otto Hehner, Professor J. M. Thomson, Mr. D. Howard, Mr. R. J. Frisweil, Mr. T. Fairley, Dr. Corfield, Dr. Wynter Blyth, and Mr. R. B. Pilcher (secretary). Mr. Justice Byrne proposed "The Institute of Chemistry," and the President, in responding, mentioned that the register of the society now contained the names of 826 Fellows and 120 Associates, while there were over 180 registered students training for the examination at the various colleges recognised by the Institute. He looked forward to the time when professional chemists would be endowed with the power of conferring diplomas, and exercising the same restrictive functions as were already possessed by the professions of the law and physic. Other toasts followed. (Abridged from the Times.) 